\title{
FIFTY YEARS OF PROGRESS IN UNDERSTANDING SEA ICE
}

\author{
By E. LYN LEWIS
}

(Institute of Ocean Sciences, Sidney, British Columbia V8L 4B2, Canada)

\begin{abstract}
The practical motivations for research on sea ice are discussed and an historical outline given of work carried out in the interval 1936-86. Advances in understanding the physical properties of sea ice and atmosphereice-ocean energy exchanges are listed. It is shown how these factors, together with an increasing ability to formulate changing ice-thickness distributions, have led to the eventual production of sophisticated models of ice movement having a useful predictive capability.
\end{abstract}

\section{INTRODUCTION}

A few outstanding contributions to our understanding of sea ice were made before 1936, but by far the greater body of knowledge has been accumulated since that date. Progress has been stimulated largely by the direct practical problems of operating shipping, submarines, aircraft, etc. in or over ice-covered waters. Studies have ranged from simple observations of the ice cover, e.g. the "ice patrols" run by Canada, the United States, U.S.S.R., and Scandinavian countries, to far more detailed observations made simulataneously above, below, and on the ice cover. The latter have allowed construction of models of sea-ice movements with some predictive capability. Since 1970 , major expenditures on sea-ice research, with a focus on its extensive mechanical properties and ice-sheet morphology, have resulted from the offshore exploration for oil and potential oil-well production problems along Arctic coasts. Developments have also been driven by the need to understand the Earth's energy balance. The eventual hope is that knowledge of the sea-ice cover will allow early detection and prediction of climatic change, sea-level variations, etc., problems of obvious human importance and high political profile.

Because of the more immediate interest in Arctic transportation and industrial exploitation problems, investigations during the period under review concentrated on the North. Climatic concerns give both polar regions similar importance but they provide a very different logistic environment for work on sea ice, the Arctic Ocean allowing ice-borne operations, whereas the Antarctic requires a properly equipped icebreaker. Only in very recent years have specific expeditions to study sea-ice conditions of fshore of Antarctica been mounted, previous efforts being expended on the very small areas of land-fast ice.

In both polar regions, most studies of ice conditions have been combined with those of oceanography and meteorology. The following discussion considers these latter topics only as boundary conditions at the surfaces of the floating ice sheet. Also neglected will be studies of the mechanical properties of sea ice as applied to the design of icebreakers, offshore drilling structures, runways, etc., as these have been dealt with in another paper by L.W. Gold (1987). There is no survey of instrumentation or observational techniques. The increasingly sophisticated capability of satellite-borne, or air-borne transducers to sense sea ice is assumed, and the results quoted without explanation; however, it should be realized that satellite-positioned ice-borne buoys giving ice-drift vectors and air pressure, from which the geostrophic wind fields can be calculated, are also now capable of providing information on boundary-layer parameters.
Only a few key papers are quoted, together with useful reviews. An exhaustive reference list would run to dozens of pages; such may be found in Untersteiner (1986), the proceedings of a recent NATO school on the "Geophysics of sea ice".

\section{HISTORICAL SKETCH}

Early in the review period was Soviet research to meet Northern Sea Route needs. Data were gathered from drifting ships and drifting stations (the still-continuing North Pole series) commencing with NP1 in 1937. These stations were supplemented by automatic installations transmitting meteorological information (DARMS) and by air-borne operations (the SEVER series). The classic book Arctic ice by N.N. Zubov (1945) is a landmark in our understanding. Subsequent to World War II, it became clear that the oceanography and ice characteristics of the Arctic Ocean had strategic importance militarily speaking so that, in contrast to Antarctica, much less information has been forthcoming from Soviet sources. The books by Doronin and Kheisin (1975) and Bogorodskiy and Gavrilo (1980) give extensive references to Russian work. The series entitled Transactions of the Arctic and Antarctic Institute in Leningrad is a major source of information on all aspects of work on sea ice. Occasional volumes in the series are available in English translation.

The United States effort after World War II focused on the Arctic. Of note are the Joint Services Sea Ice Physics Program, 1955-60, which operated in Labrador and Greenland followed by drift station Alpha during the International Geophysical Year, 1957-58, when studies of heat and mass balance, and ice structure were undertaken. This station was placed on a fragment broken off from the ice shelf north of Ellesmere Island and moved in a circular trajectory over the Canada Basin of the Arctic Ocean (the Beaufort Sea gyre), a result of the prevalent wind fields in that area. Subsequent "ice-island" drifting stations were T3 (Fletcher's Ice Island) and the Arlis stations, which were followed by the sea-ice-borne joint U.S.-Canadian Arctic Ice Dynamics Joint Experiment (AIDJEX, 1971-76), the first of these operations to bring major scientific sources to bear on our understanding of ice dynamics and the predictability of ice movement. The present marginal ice-zone experiment (MIZEX), focused on the dynamics and thermodynamics of the pack-ice-open-ocean edge, is a multi-nation undertaking with major backing by the United States.

Since 1957, profiles of the under surface of the sea ice, obtained from traversing submarines using upwardlooking sonar, have been acquired but little of these U.S. data has emerged from military files. However, such information taken from British nuclear submarines, allied to information obtained from Canadian aircraft using a laser profilometer and flying along the same traverse, has enabled the statistics of the upper and lower surfaces of the sea-ice sheet to be compared. Individually and in comparison this has allowed many important parameters to be calculated, e.g. frequency of leads, average ice thicknesses, the probability of encountering a pressure-ridge keel depth in excess of a certain magnitude per kilometer of track. Such information has obvious industrial and military application. 
Offshore industrial developments, particularly in the Canadian and the U.S. Arctic, have given rise to a large number of both government- and industry-funded studies associated with potential environmental consequences and with design parameters for structures. Examples are studies of the cross-section of pressure ridges, the probability of them impinging on a structure, "ride up" of ice on a shore line, production of rubble fields around structures, and the prediction of sea-ice conditions in terms of wind and water fields. The Canadian Beaufort Sea Program of 1975 was followed by a continuing series of studies under the Office of Energy Research and Development and the Arctic Petroleum Operators Association, while for the north coast of Alaska the U.S. Continental Shelf Environmental Assessment Program (OCSEAP) gave rise to a major increase in understanding of the interaction of sea ice on continental shelves. Transport of minerals including oil and potential transport of liquified natural gas (the Polar Gas Project) through the thick first-year sea ice of the Canadian Arctic Archipelago gave rise to extensive studies of oceanographic conditions and the sea ice in the area. Government-funded studies, for example on probable pollutant transport routes, behaviour of oil in sea ice, hazards to under-water installations, etc., were supplemented by industrially funded work with direct application to vessel performance, harbour design, and ice-bearing strengths. Both produced data having important geophysical applications. It mut be assumed that similar extensive studies have been carried out along the Arctic Sea Route of the U.S.S.R.

In northern Europe, Norwegian studies have been concentrated on Fram Strait where both remote sensing and, recently, upward-looking sonar techniques of observing ice moving through the area have been supplemented by a satellite-position buoy program extending into the Arctic Ocean proper (Vinje and Finnekosa, 1986). Proposals to drill offshore of Svalbard have led to local studies of sea ice and the Barents Sea as a whole is now an area of active study. Transport problems in the Baltic were studied by Finnish investigators as early as 1846. Aerial reconnaissance commenced in the 1930s and a series of ice atlases has been prepared. This work has been supplemented by studies of ice properties and dynamics, leading to the development of an operational ice-forecasting model in use since 1977 (Leppäranta, 1981). Danish work has naturally concentrated on the conditions along the Greenland coast; they have specialized in remote-sensing equipment and data interpretation therefrom (Gudmandsen, 1983).

Studies of the physical properties of offshore Antarctic sea ice are of recent origin, though atlases of ice conditions based on observations from ship tracks have been long available. Recent voyages specifically to study sea ice and oceanography have been those of Somov (U.S.S.R., 1981) and Polarstern (FRG, 1986). It is becoming clear that the crystallographic structure of sea ice in Antarctica is usually different from that found in the Arctic.

\section{PHYSICAL PROPERTIES OF SEA ICE}

The phase diagram of sea ice was first given by Assur (1958) and since then it has been confirmed by Richardson (1966). The basic crystal structure, a horizontal layering into polycrystalline, transition, and columnar regions explicable in terms of the hexagonal nature of the ice crystal and its dendritic axes was also available about this time (Weeks, 1958). The first work on brine drainage from sea ice, that is its salinity as a function of time after formation, appears to be that of Weeks and Lee (1962) working off Hopedale, Labrador. Bennington (1963) made observations on the crystal structure associated with this phenomenon, and Lake and Lewis (1970) analysing a massive block of first-year sea ice published the main geometric features of the brinedrainage channels and their frequency. These authors also showed that brine exchange with the underlying ocean occurred in a pulsating manner, a deduction that was confirmed by laboratory experiments (Eide and Martin, 1975).

Many studies on the physical properties of sea ice have been conducted at the Institute of Low Temperature Science at Hokkaido University, Japan. Of particular interest and importance were those of Ono (1968) on the thermal properties of sea ice, and these are still used in conjunction with Schwerdtfeger's (1963), work to provide parameters for heat-flow calculations. Lewis (1966) provided the first longterm temperature-profile measurements through a growing first-year sea-ice sheet and computed thermal properties as a function of position within the sheet; also shown experimentally was the flow of sensible heat from the underlying ocean. Sub-structures in the growth of sea ice were investigated by Weeks and Loftgren (1966) in terms of theories developed by metallurgists. The azimuthal direction of the $c$-axis in the ice crystals of the columnar region (where it is horizontal) was explained by Weeks and Gow (1978) in terms of local interface water currents. Their later conclusions were substantiated by cold-room experiments.

Investigations of the electro-magnetic properties of sea ice have extended from the short-wave region, where its presence has a significant effect on radio communications, through the micro-wave band, where its properties are most important to the interpretation of data from active and passive micro-wave instruments in satellites, through to the optical, where the albedo is dependent on reflection coefficients and the penetration of incident solar radiation through the ice sheet is sufficient to cause quite measurable heating in the underlying water. Recent papers referring to previous work are (optical) Grenfell and Perovich (1984) and (micro-wave) Morey and others (1984).

The structure of pressure ridges has been a topic of concern to many investigators, especially those from the U.S. Army Cold Regions Research and Engineering Laboratory, a recent paper of importance being Kovacs (1983). It has been shown that by working in a centrifuge it is possible to scale ice fields for some purposes (Langhorne and Robinson, 1983) and currently work is under way in Cambridge, U.K., to model pressure-ridge formations at accelerations up to $500 \mathrm{G}$. In the late 1950s, 1960 s, and early 1970s, very many studies were conducted on the small-scale mechanical properties of sea ice with a view to practical engineering applications. Later work has shown that seldom are properties so measured relevant when ice sheets having horizontal dimensions of metres and tens of metres are involved.

A good general reference to the physical properties of Arctic ice is Weeks and Ackley (1982). Offshore Antarctic ice structure is presently seeing a surge in understanding with a number of papers in press; Gow and others (1982) gives a starting point.

\section{ENERGY AND MASS BALANCES}

Together with ice dynamics, this subject determines the oceanic part of the Earth's heat balance in polar regions and its variability, which is particularly sensitive to the sea-ice cover because of the great change in albedo between open water and sea ice. A positive feed-back mechanism makes the ice extent a very sensitive indicator of the state of this balance. Open water within the ice is also of extreme importance as heat loss per unit area therefrom in winter may exceed that through the sea ice by two orders of magnitude. Studies of the overall energy balance of a sea-ice sheet were the concern of Fletcher (1965), and Maykut and Untersteiner (1971) produced a still-current model of heat flow through a sea-ice sheet and its seasonal variations including both growth and ablation conditions. Maykut has continued this work (Maykut, 1982) and the importance of the open-water condition has produced a number of works on the energy loss from polynyas and leads (Topham and others, 1983; Andreas and Murphy, 1986). This last reference attempts to produce parameters suitable for modelling purposes. Such studies may then be combined with the statistics of a sea-ice cover derived from submarine/aircraft profiling to give average values for energy exchange over large areas of ice. A future hope is to be able to incorporate detailed information on the extent and thickness categories of the ice cover, such as may be gathered by synthetic aperture radar and passive micro-wave sensors on a satellite, to produce the first overall and comprehensive understanding of changing ocean/atmosphere energy exchange over the polar oceans as a whole. 


\section{ICE COVER AND MORPHOLOGY}

Operational requirements have made this topic of primary importance since early times. Almost all nations needing to navigate ships in ice-covered waters have collected a series of observations therefrom and produced atlases and instructions for use on subsequent voyages. Early works of this type were ice atlases covering the Soviet Arctic (Armstrong, 1958), the Canadian Arctic (Swithinbank, 1960), and an atlas of the oceanography of Antarctic waters including ice conditions (U.S. Navy Hydrographic Office, 1957). The Canadian Arctic pilot and the British Antarctic pilot have gone through a series of editions and give full details of the ice to be expected, port-entry conditions, etc. Modern aerial reconnaissance generally replaced the use of ice atlases giving more or less immediate reports on local conditions plus short-term forecasts. For example, weekly ice charts have been produced by the Norwegian Meteorological Institute since 1970, while information from icepatrol aircraft combined with satellite-derived information presently allows production of daily charts for use by ships in Canadian waters which may be received directly by facsimile transmission. An early attempt to provide useful "real-time" information for fishing fleets in the Sea of Okhotsk was a land-based radar network constructed along the north coast of Hokkaido Island (Tabata and others, 1969).

As outlined above, the sea-ice cover topography has been investigated by laser profilometer and upward-looking sonar data. In the application of these instruments and construction of analytic techniques for data reduction and analysis, a leading role has been played by Wadhams and his collaborators; Wadhams and Davy (1986) on pressureridge spacing and draft is a good lead into previous work.

Imaging of sea ice by satellite-borne visual and infrared scanners, active and passive micro-wave sensors, has produced and continues to produce a revolution in large-scale data acquisition on ice cover and type. Work is still proceeding on the unambiguous identification of various sea-ice types by simultaneous recording of images in a number of frequency bands. A recent review is that of Swift and others (1985).

\section{DYNAMICS AND MODELS}

Prediction of movement of a sea-ice sheet requires an understanding of how to represent the wind- and waterdrag forces acting on the sheet, the thermodynamics of its growth and ablation, and provision of some method of parameterizing the ice-thickness distribution. The dynamic response to applied forces also requires the definition of a realistic "constitutive law" which, for example, differentiates between compressive and extensive movements of the ice field. An early representation was due to Campbell (1965), while the current model that has been modified and extended for operational application is due to Hibler (1979). Many people have contributed to developments over the period, a very major advance being AIDJEX. A review of these results is available in Pritchard (1980). Papers which, with their references, summarize approaches to components of the dynamic problems are Overland (1985) (wind drag), McPhee (1983) (water drag), and Thorndike and others (1975) (ice-thickness distribution). These investigations considered the ice sheet as a continuum, but many of the most important regions for human activity are the ice edges, the marginal ice zone, where prediction of conditions becomes of extreme importance for lightly protected shipping. These are also the areas of major ocean-atmosphere energy exchange and the ice-edge location, apart from showing seasonal variations, also exhibits inter-annual change. The currently progressing Marginal Ice Zone Experiment (MIZEX) operations are in the Greenland and Bering Seas, and the MIZEX Bulletin gives current results. Interaction between ice and waves is particularly important in this area and the studies initiated in the Southern Ocean (Robin, 1963) have been continually extended in many publications by his co-workers to the marginal ice zone (Wadhams and others, 1986).

A most important use of all the information and understanding acquired as described above is to allow pro- duction of models of the sea-ice movement, growth/decay, having adequate resolution and error bars for operational use, or for providing a realistic input into overall studies of the Earth's heat balance. Models of ice circulation, thickness-distribution patterns, and drift rates for the Arctic Ocean are reaching a highly advanced stage. This integrated approach requires an amalgamation between ice models such as those of Hibler (1979) and those of Semtner (1976) for the circulation of the Arctic Ocean, and such attempts at integration are currently in the press. The ability to make such models is, of course, a result of the development of computing capacity during the period under discussion, a revolution with effects as profound as that of the advent of remote sensing.

The major future progress of research on sea ice is probably going to come from an increasingly sophisticated use of remote-sensing data, especially that which will become available from about 1990 from satellite-borne synthetic aperture radar. With a potential resolution on a scale of metres, this will allow, for example, the extent of open-water areas within the ice to be delineated at a useful level of accuracy.

\section{Note}

The author has received input to this review from sources in most countries conducting research in the field with the notable exception of the Soviet Union. Selection from this material to conform to space limitations will inevitably show personal bias, but, it is thought, not prejudice. The author hopes that those whose favourite topics and papers have been left out will appreciate the difficulty of his task.

\section{REFERENCES}

Andreas, E.L., and Murphy, B. 1986. Bulk transfer coefficients for heat and momentum over leads and polynyas. Journal of Physical Oceanography, Vol. 16, No. 11 , p. $1875-83$.

Armstrong, T.E., and Roberts, B. 1958. Sea ice north of the U.S.S.R. Part 1. Frequency charts. Part 2. Sources of information and their evaluation. London, Hydrographic Department.

Assur, A. 1958. Composition of sea ice and its tensile strength. (In Arctic Sea Ice; National Research Council conference held at Easton, Maryland, February 24-27, 1958. Washington, DC, National Academy of Sciences, $p$. 106-38. (NRC Publication 598.))

Bennington, K.O. 1963. Some crystal growth features of sea ice. Journal of Glaciology, Vol. 4, No. 36, p. 669-88.

Bogorodskiy, V.V., and Gavrilo, V.P. 1980. Led. Fizicheskiye svoystva. Sovremennyye metody glyatsiologii [Ice. Physical properties. Present day methods of glaciology]. Leningrad, Gidrometeoizdat.

Campbell, W.J. 1965. The wind-driven circulation of ice and water in a polar ocean. Journal of Geophysical Research, Vol. 70, No. 14, p. 3279-301.

Doronin, Yu. P., and Kheysin, D. Ye. 1975. Morskoy led [Sea ice]. Leningrad, Gidrometeoizdat. [English translation: New Delhi, Amerind Publishing Co., 1977.]

Eide, L.I., and Martin, S. 1975. The formation of brine drainage features in young sea ice. Journal of Glaciology, Vol. 14, No. 70, p. 137-54.

Fletcher, J.O. 1965. The heat budget of the Arctic Basin and its relation to climate. Santa Monica, CA, Rand Corporation. (Memorandum R-444-PR.)

Gold, L.W. 1987. Fifty years of progress in ice engineering. Journal of Glaciology, Special Issue, p. 78-85.

Gow, A.J., and others. 1982. Physical and structural characteristics of Antarctic sea ice, by A.J. Gow, S.F. Ackley, W.F. Weeks, and J.W. Govoni. Annals of Glaciology, Vol. 3, p. 113-17.

Grenfell, T.C., and Perovich, D.K. 1984. Spectral albedos of sea ice and incident solar irradiance in the southern Beaufort Sea. Journal of Geophysical Research, Vol. 89, 
No. C3, p. 3573-80.

Gudmandsen, P.E. 1983. Application of microwave remote sensing to studies of sea ice. Philosophical Transactions of the Royal Society of London, Ser. A, Vol. 309, No. 1508, p. 433-45.

Hibler, W.D., III. 1979. A dynamic thermodynamic sea ice model. Journal of Physical Oceanography, Vol. 9, No. 4, p. 815-46.

Kovacs, A. 1983. Characteristics of multi-year pressure ridges. POAC 83. The Seventh International Conference on Port and Ocean Engineering under Arctic Conditions, Helsinki. Finland, 5-9 April 1983. Proceedings. Espoo, Technical Research Centre of Finland, Vol. 3, p. 172-82.

Lake, R.A., and Lewis, E.L. 1970. Salt rejection by sea ice during growth. Journal of Geophysical Research, Vol. 75, No. 3, p. 583-97.

Langhorne, P.J., and Robinson, W.H. 1983. Effect of acceleration on sea ice growth. Nature, Vol. 305, No. 5936, p. 695-98.

Leppäranta, M. 1981. An ice drift model for the Baltic Sea. Tellus, Vol. 33, No. 6, p. 583-96.

Lewis, E.L. 1966. Heat flow through winter ice. (In $\bar{O} u r a$, H., ed. Physics of Snow and Ice. International Conference on Low Temperature Science ... 1966 ... Proceedings. Sapporo, Hokkaido University. Institute of Low Temperature Science, Vol. 1, Pt. 1, p. 611-31.)

McPhee, M.G. 1983. Turbulent heat and momentum transfer in the oceanic boundary layer under melting pack ice Journal of Geophysical Research, Vol. 88, No. C5, p. 2827-35.

Maykut, G.A. 1982. Large-scale heat exchange and ice production in the central Arctic. Journal of Geophysical Research, Vol. 87, No. C10, p. 7971-84.

Maykut, G.A., and Untersteiner, N. 1971. Some results from a time-dependent thermodynamic model of sea ice Journal of Geophysical Research, Vol. 76, No. 6, p. 1550-75.

Morey, R.M., and others. 1984. Electromagnetic properties of sea ice, by R.M. Morey, A. Kovacs, and G.F.N. Cox. CRREL Report 84-2.

Ono, N. 1968. Thermal properties of sea ice. IV. Thermal constants of sea ice. [In Japanese.] Low Temperature Science, Ser. A, Vol. 26, p. 329-49.

Overland, J.E. 1985. Atmospheric boundary layer structure and drag coefficients over sea ice. Journal of Geophysical Research, Vol. 90, No. C5, p. 9029-49.

Pritchard, R.S., ed. 1980. Sea ice processes and models. Proceedings of the Arctic Ice Dynamics Joint Experiment/International Commission on Snow and Ice Symposium. Seattle and London, University of Washington Press. [IAHS-AISH Publication No. 124.]

Richardson, C., and Keller, E.E. 1966. The brine content of sea ice measured with a nuclear magnetic resonance spectrometer. Journal of Glaciology, Vol. 6, No. 43, p. 89- 100.

Robin, G. de Q. 1963. Wave propagation through fields of pack ice. Philosophical Transactions of the Royal Society of London, Ser. A, Vol. 255, No. 1057, p. 313-39.

Schwerdtfeger, P. 1963. The thermal properties of sea ice. Journal of Glaciology, Vol. 4, No. 36, p. 789-807.

Semtner, A.J., jr. 1976. Numerical simulation of the Arctic Ocean circulation. Journal of Physical Oceanography, Vol. 6, p. 409-25.
Swift, C.T., and others. 1985. Observations of the polar regions from satellites using active and passive microwave techniques, by C.T. Swift [and 7 others]. Advances in Geophysics, Vol. 27, p. 335-92.

Swithinbank, C.W.M. 1960. Ice atlas of northern Canada. Ottawa, Defence Research Board.

Tabata, T., and others. 1969. Observations on the movement of drift ice with the sea ice radar, by $T$. Tabata, M. Aota, M. Ôi, and M. Ishikawa. [In Japanese.] Low Temperature Science, Ser. A, Vol. 27, p. 295-315. [English translation: Ottawa, Defence Research Board, 1970. [Report No. T103J.]]

Thorndike, A.S., and others. 1975. The thickness distribution of sea ice, by A.S. Thorndike, D.A. Rothrock, G.A. Maykut, and R. Colony. Journal of Geophysical Research, Vol. 80 , No. 33, p. 4501-13.

Topham, D.R., and others. 1983. An investigation of a polynya in the Canadian Arctic Archipelago. 1. Introduction and oceanography, by D.R. Topham, R.G. Perkin, S.D. Smith, R.J. Anderson, and G. den Hartog. Journal of Geophysical Research, Vol. 88, No. C5, p. 2888-99.

Untersteiner, N., ed. 1986. The geophysics of sea ice. New York, Plenum Press. (NATO Advanced Science Institute Series B, Vol. 146.)

U.S. Navy Hydrographic Office. 1957. Oceanographic atlas of the polar seas. Part I. Antarctica. Washington, DC, U.S. Navy Hydrographic Office.

Vinje, T.E., and Finnekosa, Ø. 1986. The ice transport through the Fram Strait. Norsk Polarinstitutt. Skrifter, Nr. 186.

Wadhams, P., and Davy, T. 1986. On the spacing and draft distributions for pressure ridge keels. Journal of Geophysical Research, Vol. 91, No. C9, p. 10, 697-708.

Wadhams, P., and others. 1986. The effect of the marginal ice zone on the directional wave spectrum of the ocean, by P. Wadhams, V.A. Squire, J.A. Ewing, and R.W. Pascal. Journal of Physical Oceanography, Vol. 16, No. 2, p. 358-76.

Weeks, W.F. 1958. The structure of sea ice: a progress report. (In Arctic Sea Ice. National Research Council conference held at Easton, Maryland, February 24-27, 1958. Washington, DC, National Academy of Sciences, p. 96-99. (NRC Publication 598.))

Weeks, W.F., and Ackley, S.F. 1982. The growth, structure, and properties of sea ice. CRREL Monograph 82-1.

Weeks, W.F., and Gow, A.J. 1978. Preferred crystal orientations in the fast ice along the margins of the Arctic Ocean. Journal of Geophysical Research, Vol. 83, No. C10, p. 5105-21

Weeks, W.F., and Lee, O.S. 1962. The salinity distribution in young sea ice. Arctic, Vol. 15, No. 2, p. 92-108.

Weeks, W.F., and Lofgren, G. 1966. The effective solute distribution coefficient during the freezing of $\mathrm{NaCl}$ solutions. (In Öura, H., ed. Physics of Snow and Ice. International Conference on Low Temperature Science ... 1966 ... Proceedings. Sapporo, Hokkaido University. Institute of Low Temperature Science, Vol. 1, Pt 1, p. 579-97.)

Zubov, N.N. 1945. L'dy Arktiki [Arctic ice]. Moscow, Izdatel'stvo Glavsevmorputi. [English translation: U.S. Naval Oceanographic Office and American Meteorological Society, 1965.] 